\title{
Litter Materials and the Incidence of Carcass Lesions in Broilers Chickens
}

\section{-Author(s)}

Garcia RG'

Almeida Paz ICL

Caldara FR

Nääs IA ${ }^{1}$

Bueno LGF

Freitas $\mathrm{LW}^{3}$

Graciano JD ${ }^{1}$

$\operatorname{Sim} S^{3}$

1 Professor of the College of Agrarian Sciences - Federal University of Grande Dourados. Dourados, MS, Brazil.

2 Professor, UNESP. Dracena, São Paulo, Brazil.

3 Undergraduate student, Animal Science, College of Agrarian Sciences - Federal University of Grande Dourados. Dourados, MS, Brazil.

\section{-Mail Adress}

RG Garcia

College of Agrarian Sciences

Federal University of Grande Dourados.

Dourados, MS, Brazil.

E-mail: rodrigogarcia@ufgd.edu.br

\section{neywords}

Compaction, fathering, quality, substrate

\section{-Acknowledgements}

The authors are grateful to Fundação de Apoio ao Ensino, Ciência e Tecnologia do Estado de Mato Grosso do Sul (FUNDECT) for funding this study.

\section{ABSTRACT}

The aim of this study was to evaluate the effects of different litter materials on litter compaction, broiler feathering and the incidence of carcass lesions. In the experiment, 3240 one-day-old Ross ${ }^{\circledR}$ chicks were selected by sex and distributed according to a completely randomized experimental design in a $2 \times 6$ factorial arrangement (two sex and six litter materials). The following litter materials were used: wood shavings, rice husks, chopped Napier grass, 50\% sugar cane bagasse plus $50 \%$ wood shavings, $50 \%$ sugar cane bagasse plus $50 \%$ rice husks, and pure sugar cane bagasse. Litter compaction was weekly assessed using a penetrometer. On days 21, 35 and 42 of the experimental period, feathering on the back and legs was scored according to a 0 - 10 scale. On day 42, birds were slaughtered and the presence of bruises, scratches and footpad lesions was recorded. Litter material had no effect on bird feathering. Carcass lesions (scratches, bruises and footpad lesions) were influenced by the litter material evaluated. Birds reared on sugarcane bagasse and chopped Napier grass presented more scratches, bruises and footpad lesions than the others. Dermatitis was more evident in birds reared on sugarcane bagasse, chopped Napier grass and the combination of litter materials. It was found that males presented higher incidence of dermatitis and footpad lesions than females. Each litter material presented different compaction degrees, which increased along the experimental period. Sugarcane bagasse, chopped Napier grass and the combination of bedding materials presented the highest degree of compaction, compared with wood shavings and rice husks.

\section{INTRODUCTION}

Wood shavings and sawdust are traditionally used as litter material in poultry houses. However, the limited availability and high cost of suitable litter material have motivated, with relative success, the search for alternative materials, such as peanut hulls, rice husks, corn cobs, coffee husks, and several types of grasses, including sugarcane bagasse (Huang et al., 2009; Qiu \& Guo, 2010; Santos et al., 2000).

Independently of the specific substrate, litter must be properly managed to control humidity and ammonia and dust production, as well as to prevent the replication of disease agents and the proliferation of pests (Hernandes et al., 2002, Angelo et al., 1997; Sorbara et al., 2000, Toghyani et al., 2010). The type of litter material significantly influences broiler performance and carcass quality (Malone et al., 1983) and may stimulate specific behaviors in poultry. Toghyani et al. (2010) showed that broilers reared on rice husks presented significant body weight, feed intake and antibody titer reduction $(p<0.05)$; however, no significant effect on the carcass yield and feed conversion was 
detected. Those authors also established that, when sand was added to the litter, birds displayed similar behavior to that observed in nature.

Contact and footpad dermatitis cause significant economic problems for the poultry industry and are attributed to the inadequate litter conditions, particularly to excessive moisture (Martland, 1984; Greene et al., 1985; Mcllroy et al., 1987). Litter moisture content may influence flock yield and may cause carcass lesions, and this is directly associated with the volatilization of ammonia from the microbial metabolism in the excreta (Traldi et al., 2004), resulting in increased respiratory and eye lesions, and consequent economic and welfare loss.

The incidence and severity of footpad dermatitis in broilers are high and affect product quality (Bilgili \& Hess, 1995; Bilgili et al.,1999) and bird welfare (Bradshaw et al., 2001). As broilers spend most of their time on the litter, its material is one of the most important factors related to the occurrence of feet dermatitis (Bilgili et al., 2009). Bedding materials with large and sharp particles may result in a higher incidence of injuries due to their abrasive action.

The aim of this study was to evaluate the effects of different materials used as broiler litter on litter compaction, broiler feathering and carcass quality.

\section{MATERIAL AND METHODS}

The experiment was approved by the Ethics Committee of the Federal University of Grande Dourados (protocol number 03/2010).

\section{Birds, management and treatments}

The experiment was conducted at the Poultry Experimental Sector of the College of Agrarian Sciences, Federal University of Grande Dourados, state of Mato Grosso, Brazil, in a $50 \mathrm{~m}$ long, $10 \mathrm{~m}$ wide and $3 \mathrm{~m}$ tall broiler house. The house was equipped with bell drinkers, tube feeders, side curtains, fans and foggers to cool and control the house internal temperature. One $250 \mathrm{~W}$ infrared lamp perpen was used for brooding. Artificial lighting was provided using $40 \mathrm{~W}$ light bulbs (average $22 \mathrm{~lx}$ ) in a 24 hours of light per day regime during the entire rearing period. A flock density of 16 birds $\mathrm{m}^{-2}$ was adopted. New litter

$\mathrm{DBT}=$ Dry bulb temperature; $\mathrm{RH}=$ relative humidity. was provided in all pens. Birds were vaccinated in the hatchery against Marek's disease and at 10 days of age, against Newcastle disease in the drinking water. All birds were offered feed and water ad libitum during the entire experimental period. The feeding program included the following phases: a starter diet (days 1-21), a grower diet (days 22-35), and a finisher diet (days 36-42).

In this experiment, 3,240 one-day-old strain Ross ${ }^{\circledR}$ chicks were separated by sex and distributed according to a completely randomized experimental design in 6 $\times 2$ factorial arrangement, with two sexes and six litter materials (sugarcane bagasse Saccharum L. - T1, wood shavings - T2, rice husks - T3, chopped Napiergrass Pennisetum pupureum - T4,50\% sugarcane bagasse plus $50 \%$ rice husks $-\mathrm{T} 5$, and $50 \%$ sugarcane bagasse plus $50 \%$ wood shavings - T6). Each treatment had five replicates of 54 birds each.

New litter was provided in all pens and at a height of $0.10 \mathrm{~m}$. Sugarcane bagasse presented $400 \mathrm{~kg}$ $\mathrm{m}^{-3}$ initial density and 35\% moisture content. Wood shavings had an initial density of $30 \mathrm{~kg} \mathrm{~m}^{-3}$ and $15 \%$ moisture content. Rice husks had an initial density of $80 \mathrm{~kg} \mathrm{~m}^{-3}$ and $15 \%$ moisture content. Napier grass had an initial density of $70 \mathrm{~kg} \mathrm{~m}^{-3}$ and $24 \%$ moisture. For the other combinations, average values were adopted. Wood shavings particles size ranged between 0.01 and $0.05 \mathrm{~m}$, and rice husks particle size was $0.012 \mathrm{~m}$. Napier grass was purchased from local farms and then chopped into 0.02-0.03 m particles and exposed to the sun for drying. Sugarcane bagasse was obtained directly from ethanol plants of the region of Dourados, MS. The combinations of materials were controlled using equal amounts of the different materials and raking until the height of $10 \mathrm{~cm}$ was reached. Compaction was evaluated on days 7, 14, 21, 28, 35, and 42. Environmental data were recorded daily and the weekly average was calculated (Table 1).

\section{Evaluation of feathering, lesions incidence and litter compaction}

Feathering was evaluated according to the standard 0-10 score scale proposed by Garcia et al. (2002).

Table 1 - Mean environmental data recorded inside the housing during the experimental period.

\begin{tabular}{|c|c|c|c|c|c|c|c|c|c|c|c|c|}
\hline \multirow{3}{*}{ Factor } & \multicolumn{12}{|c|}{ Grow out day } \\
\hline & \multicolumn{2}{|c|}{7} & \multicolumn{2}{|c|}{14} & \multicolumn{2}{|c|}{21} & \multicolumn{2}{|c|}{28} & \multicolumn{2}{|c|}{35} & \multicolumn{2}{|c|}{42} \\
\hline & Min & Max & Min & Max & Min & Max & Min & Max & Min & Max & Min & Max \\
\hline $\mathrm{DBT}\left({ }^{\circ} \mathrm{C}\right)$ & 21.2 & 30.5 & 22.7 & 34.4 & 18.1 & 28.4 & 23.6 & 34.3 & 20.5 & 35.3 & 24.8 & 36.1 \\
\hline $\mathrm{RH}(\%)$ & 43.4 & 81.3 & 37.6 & 79.3 & 51.5 & 83.7 & 46.4 & 75.4 & 38.1 & 72.9 & 46.2 & 80.3 \\
\hline
\end{tabular}


The degree of feathering on the back and thighs of a sample of birds representing $10 \%$ of the population in each pen was scored on days 28, 35 and 42 .

The incidence of carcass lesions was determined in 15 randomly selected birds per treatment. Birds were individually identified using numbered leg bands and taken to the experimental processing plant. After slaughter and plucking, birds were inspected for the presence of bruises, scratches and footpad lesions. The types of lesions found and bird identification number were recorded in a specific spreadsheet. The presence of lesions was recorded as recommended by Garcia et al. (2002).

Litter compaction was assessed weekly at three location in each pen. Visual assessment was used to identify the presence of caking. A penetrometer was applied to determine compaction strength $\left(\mathrm{kgf}^{-2}\right)$.

House relative humidity was recorded daily in the geometric center of the house using two digital thermo hygrometers. Air temperature was recorded daily at 08h:00 min at two location sequally distant from the geometric center of the house using minimummaximum thermometers.

Data were submitted to one-way analysis of variance and means were compared by the test of Tukey. The Kruskal-Wallis test was used to analyze lesion incidence (non-parametric data). The statistical software PROC GLM/SAS (2009) was used for processing the data and all statements of significance were based upon $p<0.05$.

\section{RESULTS AND DISCUSSION}

The different litter materials did not influence $(p>$ $0.05)$ feathering score in neither of the evaluated body regions (Table 2 ). Similar results were obtained by Huang et al. (2009) and Toghyani et al. (2010). Females presented earlier feathering than males, and obtained higher average scores at the end of the experimental period. The late feathering of males allows higher heat dissipation and consequently helps when birds are in heat stress; however, it leaves the skin unprotected from direct injuries (Cahaner et al., 2008).

Several factors may influence the feathering of broilers, particularly feed nutritional levels and environmental temperatures. Dahlke et al. (2005) observed a reduction of the total feather weight on days 28 and 42 of the grow out when broilers were reared at warm temperatures. Today reduced feathering is considered beneficial when broilers are reared in hot climates, as it increases heat dissipation; however, it impairs carcass quality. Edens et al. (2000) found that chickens reared in cold environments presented higher feathering index, and the authors consider it an important characteristic for the maintenance of thermal homeostasis.

The material used as litters should protect birds from the impact and the friction on the poultry house floor, and this is particularly important when footpad lesions are considered, as their incidence is closely related to the quality and quantity of litter material. The reduction in litter particle size results in lower moisture content, higher density and lower height during the grow out period, minimizing the incidence of tibial diseases (Lima \& Nääs, 2005) and lesions in the tarsal-metatarsal joint, footpads and breast (Oliveira et al., 2004). This consequently reduces condemnations of these parts in the processing plant, and therefore, economic losses. High litter moisture may lead to cycles of wetting and drying that compact the material and causes burns and footpad dermatitis in broilers. This has been reported as economic problem for industrial broiler and turkey production in the United Kingdom, North America, Australia and Brazil (Santos et al., 2002).

Table 2 - Feathering scores on the back (B) and thighs (T) of broilers reared on different litter materials.

\begin{tabular}{|c|c|c|c|c|c|c|}
\hline \multirow{3}{*}{ Treatment } & \multicolumn{6}{|c|}{ Grow out day } \\
\hline & \multicolumn{2}{|c|}{28} & \multicolumn{2}{|c|}{35} & \multicolumn{2}{|c|}{42} \\
\hline & B & $T$ & B & $T$ & B & $T$ \\
\hline \multicolumn{7}{|l|}{ Male } \\
\hline $\mathrm{T} 1$ & 7.80 & 6.30 & 9.30 & 7.00 & 9.50 & 8.00 \\
\hline $\mathrm{T} 2$ & 7.60 & 6.10 & 9.50 & 6.40 & 9.60 & 7.30 \\
\hline T3 & 7.20 & 6.10 & 9.40 & 6.60 & 9.60 & 8.20 \\
\hline T4 & 7.30 & 5.80 & 9.60 & 6.30 & 9.80 & 7.80 \\
\hline T5 & 7.20 & 5.60 & 9.20 & 7.00 & 9.60 & 8.20 \\
\hline T6 & 7.20 & 5.30 & 9.20 & 7.00 & 9.30 & 8.10 \\
\hline Mean & $7.40 \mathrm{~B}$ & $5.90 \mathrm{~B}$ & 9.40 & $6.70 \mathrm{~B}$ & 9.60 & $7.90 \mathrm{~B}$ \\
\hline $\mathrm{CV} \%$ & 9.50 & 8.40 & 9.10 & 8.50 & 9.40 & 8.70 \\
\hline \multicolumn{7}{|l|}{ Female } \\
\hline $\mathrm{T1}$ & 8.40 & 6.70 & 9.70 & 7.70 & 9.90 & 8.80 \\
\hline $\mathrm{T} 2$ & 8.30 & 6.50 & 9.80 & 7.60 & 10.00 & 8.80 \\
\hline T3 & 8.20 & 6.40 & 9.60 & 7.00 & 9.80 & 8.00 \\
\hline T4 & 8.27 & 6.60 & 9.87 & 7.13 & 9.93 & 8.20 \\
\hline T5 & 8.10 & 6.40 & 10.00 & 7.10 & 10.00 & 8.40 \\
\hline T6 & 8.50 & 6.40 & 9.80 & 7.300 & 10.00 & 8.50 \\
\hline Mean & $8.30 \mathrm{~A}$ & $6.50 \mathrm{~A}$ & 9.80 & $7.30 \mathrm{~A}$ & 9.90 & $8.50 \mathrm{~A}$ \\
\hline$C \vee \%$ & 9.80 & 6.10 & 8.60 & 8.80 & 8.10 & 9.10 \\
\hline
\end{tabular}

T1 = sugarcane bagasse (Saccharum L.); T2 = wood shavings; T3 = rice husks; T4 = chopped Napiergrass (Pennisetum pupureum); T5 $=50 \%$ sugarcane bagasse (Saccharum L.) plus 50\% rice husks, and T6 $=50 \%$ sugarcane bagasse (Saccharum L.) plus 50\% wood shavings. Means followed by the same capital letters in the same column are not different by the test of Tukey ( $p>0.05)$. 
Table 3 - Incidence of carcass lesions in broilers reared on different litter materials.

\begin{tabular}{|c|c|c|c|c|}
\hline \multirow{2}{*}{ Treatment } & \multicolumn{4}{|c|}{ Lesion (\%) } \\
\hline & Scratches & Bruises & Footpad lesions & Dermatitis \\
\hline \multicolumn{5}{|l|}{ Males } \\
\hline T1 & $24.62 \mathrm{~A}$ & $4.80 \mathrm{~A}$ & $27.43 B$ & $51.00 \mathrm{~A}$ \\
\hline $\mathrm{T} 2$ & $8.57 C$ & $1.24 \mathrm{C}$ & $7.14 \mathrm{D}$ & $14.29 \mathrm{C}$ \\
\hline T3 & $4.29 \mathrm{C}$ & $2.16 \mathrm{C}$ & $7.18 \mathrm{D}$ & $15.71 \mathrm{C}$ \\
\hline T4 & $24.29 \mathrm{~A}$ & $5.87 \mathrm{~A}$ & $35.71 \mathrm{~A}$ & $27.43 B$ \\
\hline T5 & $16.43 B$ & $3.27 \mathrm{~B}$ & $21.43 C$ & $28.57 \mathrm{~B}$ \\
\hline T6 & $16.29 B$ & $3.18 \mathrm{~B}$ & $21.14 C$ & $28.57 \mathrm{~B}$ \\
\hline Mean & $15.75 \mathrm{~A}$ & 3.42 & $20.00 \mathrm{~A}$ & 27.60 \\
\hline CV\% & 82.41 & 54.27 & 56.87 & 67.85 \\
\hline \multicolumn{5}{|l|}{ Females } \\
\hline T1 & $20.34 \mathrm{~A}$ & $4.58 \mathrm{~A}$ & $26.14 \mathrm{~B}$ & $50.25 \mathrm{~A}$ \\
\hline $\mathrm{T} 2$ & $7.24 C$ & $2.16 \mathrm{C}$ & $6.12 \mathrm{D}$ & $14.19 \mathrm{C}$ \\
\hline T3 & $7.14 \mathrm{C}$ & $1.18 \mathrm{C}$ & $7.22 \mathrm{D}$ & $11.43 C$ \\
\hline T4 & $19.14 \mathrm{~A}$ & $4.14 \mathrm{~A}$ & $28.57 \mathrm{~A}$ & $26.43 B$ \\
\hline T5 & 14.29B & $3.12 \mathrm{~B}$ & $21.48 \mathrm{C}$ & $27.29 B$ \\
\hline T6 & 14.29B & $3.17 \mathrm{~B}$ & $21.72 \mathrm{C}$ & $27.14 \mathrm{~B}$ \\
\hline Mean & $13.74 \mathrm{~B}$ & 3.05 & $18.54 \mathrm{~B}$ & 26.12 \\
\hline CV\% & 65.23 & 50.22 & 59.43 & 81.24 \\
\hline
\end{tabular}

$\mathrm{T} 1$ = sugarcane bagasse (Saccharum L.); T2 = wood shavings; $\mathrm{T} 3=$ rice husks; $\mathrm{T} 4=$ chopped Napier grass (Pennisetum pupureum); T5 $=50 \%$ sugarcane bagasse (Saccharum L.) plus 50\% rice husks, and T6 $=50 \%$ sugarcane bagasse (Saccharum L.) plus $50 \%$ wood shavings. Means followed by the same capital letters in the same column are not different by the test of Kruskal-Wallis ( $p>0.05$ ).

Males presented more lesions than females in all treatments ( $p<0.05$; Table 3 ). The incidence of scratches, bruises and footpad lesions was higher in broilers reared on sugarcane bagasse bedding (T1) and in the chopped Napier grass (T4) than in the other treatments (T2, T3, T5 and T6), independently of sex. It was observed that, the incidence of footpad dermatitis was higher in broilers on sugarcane bagasse (T1), followed by chopped Napier grass (T4), and the combinations of the materials (T5 and T6). Environmental factors may have influenced these results as high relative humidity and high dry bulb temperature were recorded during the last phase of the grow out (Table 1). The presence of breast blisters was not observed in any treatment. Traldi et al. (2007) also found no difference in breast lesions when studying carcass lesions in broilers reared on new or reused litter.

In a study of eight different litter substrates, Bilgili et al. (2009) found that bedding materials had little influence on broiler performance. However, the incidence of dermatitis was significantly different ( $p<$ 0.05 ) among litter materials, possibly due to differences in moisture content. Sorbara et al. (2000), comparing citrus pulp with wood shavings as litter material for broilers, did not find any significant difference in the incidence of breast, tarsal-metatarsal joint and footpad lesions between treatments, concluding that litter material did not influence carcass quality. Santos et al. (2002), in a study on the incidence of footpad lesions in broilers, concluded that the most probable cause of these lesions was excessive litter moisture. Another important and significant influence on carcass quality is flock density (Garcia et al., 2002). A high density of birds per square meter may impair litter quality, and may also negatively affect broiler performance and increase mortality (Oliveira et al., 2004).

The higher incidence of carcass lesions in males compared with females (Table 3) may be explained by the fact that they were larger than the females. In most animal species the males are larger and heavier than the females, and this is partially due to the presence of gonadotrophic hormones, such as testosterone. The heavier the animal, the greater is the pressure on its limbs. In broilers, this is closely related to the appearance of footpad lesions. Moreover, broilers present later feathering than females, resulting in a longer period of exposure and skin contact with the environment and the litter, which may lead to a significantly higher incidence of dermatitis. The results of the present study are consistent with those of Zavala (1997), working with heavy broilers, found that males presented higher incidence of carcass lesions and footpad dermatitis than females.

There was no influence of litter material $(p>0.05)$ on litter compaction, as evaluated on days 7, 21 and 42 of the grow out (Table 4). However, on days 28 and 35 , pens rearing males on wood shavings presented the highest compaction value $(p<0.05)$ and pens rearing males on rice husks, the lowest value (Table 4 ).

When investigating the efficiency of alternative materials for poultry litter not only the material itself should be evaluated, but also its adequate management in order to control the moisture content, especially the production of dust and ammonia, thereby preventing the onset of carcass lesions (Angelo et al., 1997; Sorbara et al., 2000; Hernandes et al., 2002; Toghyani et al., 2010).

\section{CONCLUSION}

Broiler feathering was not influenced by the 


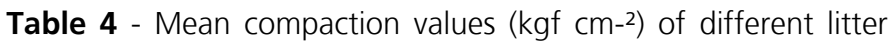
materials.

\begin{tabular}{|c|c|c|c|c|c|c|}
\hline \multirow{2}{*}{ Day } & \multicolumn{6}{|c|}{ Male } \\
\hline & T1 & T2 & T3 & T4 & T5 & T6 \\
\hline 7 & 0.90 & 0.80 & 0.74 & 0.83 & 0.90 & 0.95 \\
\hline 14 & $2.86 a$ & $1.06 \mathrm{~b}$ & $1.24 b$ & $2.55 a$ & $2.67 a$ & $2.96 a$ \\
\hline 21 & $2.82 a$ & $1.27 \mathrm{~b}$ & $1.60 \mathrm{~b}$ & $2.79 a$ & $2.79 a$ & $2.56 a$ \\
\hline 28 & $3.51 a$ & $2.21 b$ & $2.15 b$ & $3.62 a$ & $3.19 a$ & $3.18 a$ \\
\hline 35 & $3.82 a$ & $2.55 b$ & $2.58 \mathrm{~b}$ & $3.97 a$ & $3.17 a$ & $3.14 a$ \\
\hline 42 & 3.50 & 3.93 & 3.48 & 3.65 & 3.56 & 3.47 \\
\hline Mean & $2.90 a$ & $1,97 \mathrm{~b}$ & $1.96 \mathrm{~b}$ & $2.90 a$ & $2.71 \mathrm{a}$ & $2.71 \mathrm{a}$ \\
\hline CV\% & 6.15 & 6.24 & 6.18 & 7.95 & 8.12 & 8.74 \\
\hline \multirow{2}{*}{ Day } & \multicolumn{6}{|c|}{ Female } \\
\hline & T1 & T2 & T3 & T4 & T5 & T6 \\
\hline 7 & 0.81 & 0.72 & 0.68 & 0.81 & 0.82 & 0.86 \\
\hline 14 & $2.12 a$ & $0.98 b$ & $1.21 \mathrm{~b}$ & $2.21 \mathrm{a}$ & $2.21 \mathrm{a}$ & $2.54 a$ \\
\hline 21 & $2.50 a$ & $1.17 \mathrm{~b}$ & $1.40 \mathrm{~b}$ & $2.35 a$ & $2.36 a$ & $2.23 a$ \\
\hline 28 & $3.24 a$ & $2.06 \mathrm{~b}$ & $2.05 b$ & $3.41 a$ & $3.04 a$ & $3.08 \mathrm{a}$ \\
\hline 35 & $3.12 a$ & $2.10 \mathrm{~b}$ & $2.26 \mathrm{~b}$ & $3.29 a$ & $3.13 a$ & $3.01 \mathrm{a}$ \\
\hline 42 & 3.30 & 3.23 & 3.34 & 3.39 & 3.18 & 3.17 \\
\hline Mean & $2.51 a$ & $1.71 \mathrm{~b}$ & $1.82 \mathrm{~b}$ & $2.57 a$ & $2.45 a$ & $2.48 \mathrm{a}$ \\
\hline CV\% & 6.52 & 8.42 & 7.53 & 6.98 & 6.54 & 7.41 \\
\hline
\end{tabular}

$\mathrm{T} 1$ = sugarcane bagasse $($ Saccharum $\mathrm{L}$.); T2 = wood shavings; $\mathrm{T} 3=$ rice husks; T4 = chopped Napiergrass (Pennisetumpupureum); T5 $=50 \%$ sugarcane bagasse (Saccharum L.) plus 50\% rice husks, and T6 $=50 \%$ sugarcane bagasse (Saccharum L.) plus $50 \%$ wood shavings. Means followed by the same letters in the same row are not different by the test of Tukey $(p<0.05)$

litter material; males presented later feathering compared with females, as expected. Litter material influenced the incidence of carcass lesions. Broilers reared on sugarcane bagasse and chopped Napier grass presented more scratches, bruises and footpad lesions. Dermatitis was more evident in birds reared on sugarcane bagasse, chopped Napier grass and the studied combinations of litter materials. Males presented higher incidence of dermatitis and footpad lesions compared with females. Litter compaction was influenced by litter material and increased during the grow out. Sugarcane bagasse, chopped Napier grass and the combinations of litter materials presented higher degree of compaction, compared with wood shavings and rice husks.

\section{REFERENCES}

Ângelo JA, Gonzáles E, Kondo N. Material de cama: qualidade, quantidade e efeito sobre o desempenho de frangos de corte. Revista Brasileira de Zootecnia 1997; 26(1):121-130

Bilgili SF, Montenegro Gl, Hess JB, Eckman MK. Live performance, carcass quality and deboning yields of broilers reared on sand as a litter source. Journal of Applied Poultry Research 1999; 8:352-361.

Bilgili SF, Hess JB. Placement density influences broiler carcass grade and meat yields. Journal of Applied Poultry Research 1995; 4:384-389, 1995.

Bilgili SF, Hess JB, Blake JP, Macklin KS, Saenmahayak B, Sibley JL. Influence of bedding material on footpad dermatitis in broiler chickens. Journal of Applied Poultry Research 2009; 18:583-589.

Bradshaw RH, Kirkden RD, Broom DM. A review of the etiology and pathology of leg weakness in broilers in relation to welfare. Avian Poultry Biology Review 2001; 13:45-103.

Cahaner A, Ajuh JA, Schultze MS, Azoulay Y, Druyan S, Zárete AV. Effects of the genetically reduced feather coverage in naked neck and featherless broilers on their performance under hot conditions. Poultry Science 2008; 87:2517-2527.

Dahlke F, Gonzales EG, Furlan RL, Gadelha A, Maiorka A, Faria Filho DE, Rosa PS. Efeito da temperatura ambiente sobre hormônios tireoideanos, temperatura corporal e empenamento de frangos de corte, fêmeas, de diferentes genótipos. Acta Scientiarum. Animal Sciences 2005; 27(3): 391-397.

Edens FW. Empenamento em frangos: influência de aminoácidos e minerais na dieta. Anais da Conferência APINCO de Ciência e Tecnologia Avícolas; 2000; Campinas, São Paulo. Brasil. Campinas: FCTA; 2000. p. $81-100$

Garcia RG, Mendes AA, Garcia EA, Nääs IA, Moreira J, Almeida ICL, Takita TS. Efeito da densidade de criação e do sexo sobre o empenamento, incidência de lesões na carcaça e qualidade da carne de peito de frangos de corte. Revista Brasileira de Ciência Avícola 2002; 4(1):1-9.

Greene JÁ, McCracken RM, Evans RT. Contact dermatitis of broilers clinical and pathological findings. Avian Pathology 1985; 14:23-38.

Hernandes R, Cazetta JO, Moraes VMB. Frações nitrogenadas, glicídicas e amônia liberada pela cama de frangos de corte em diferentes densidades e tempos de confinamento. Revista Brasileira de Zootecnia 2002; 31(4):1795-1802.

Huang Y, Yoo JS, Kim HJ, Wang Y, Chen YJ, Cho JH, Kim IH. Effect of bedding types and different nutrient densities on growth performance, visceral organ weight, and blood characteristics in broiler chickens. Journal of Applied Poultry Research 2009; 18:1-7.

Lima AMC, Nääs IA. Evaluating two systems of poultry production: conventional and free-range. Revista Brasileira de Ciência Avícola 2005; 7(4):215-220

McllroySG, Goodall EA, Mcmurray CH. A contact dermatitis of broilers epidemiological findings. Avian Pathology 1987; 16:93-105.

Malone GW, Chaloupka GW, Saylor WW. Influence of litter type and size on broiler performance: Factors affecting litter consumption. Poultry Science 1983; 62:1741-1746.

Martland MF. Wet litter as a cause of plantar pododermatitis leading to foot ulceration and lameness in fattening turkeys. Avian Pathology $1984 ; 13: 241-252$.

Oliveira MC, Ferreira HA, Cancherini LC. Efeito de condicionadores químicos sobre a qualidade da cama de frango. Arquivo Brasileiro de Medicina Veterinária e Zootecnia 2004; 56(4):536-541.

Santos EC, Cotta JTB, Muniz JA. Avaliação de alguns materiais usados como cama sobre o desempenho de frangos de corte. Ciência Agrotécnica 2000: 14(4):1024-1030 
Santos RL, Nunes VA, Baião NC. Pododermatite de contato em frangos de corte. Arquivo Brasileiro de Medicina Veterinária e Zootecnia 2002; 54 (6):655-658

Statistical Analysis System - SAS. User's guide. Version 9.2. Cary; 2009. $634 p$

Sorbara JOB, Rizzo MF, Laurentiz AC. Avaliação da polpa peletizada como material para cama de frangos de corte. RevistaBrasileira de CiênciaAvícola 2000; 2(3):1-13.

Toghyani M, Gheisari A, Modaresi M, Tabeidian SA, Toghyani M. Effect of different litter material on performance and behavior of broiler chickens. Applied Animal Behaviour Science 2010; 122:48-52.

Traldi COM, Duarte KF, Moraes VM. Avaliação de probióticos na dieta de frangos de corte criados em cama nova ou reutilizada. Revista Brasileira de Zootecnia 2007; 36(3):660-665.

Quio G, Guo M. Quality of poultry litter-derived granular activated carbon. Bioresource Technology 2010; 101:379-386.

Zavala G. Manejo de problemas locomotores en reproductoras pesadas. Avicultura Profesional 1997; 15(4):26-28. 